\title{
RESPON IMUN SELULER DAN HUMORAL MENCIT YANG DIIMUNISASI KANDIDAT VAKSIN DNA DENGUE BERBASIS GEN preM-E SEROTIPE 4 STRAIN INDONESIA
}

\author{
Eleanor Louana Urfa1 ${ }^{1}$, Beti Ernawati Dewi², T. Mirawati Sudiro²
}

\begin{abstract}
Abstrak
Infeksi virus dengue (DENV) terkadang tanpa gejala atau dapat menunjukkan gejala klinis yang luas, berkisar dari sindrom flu ringan (dengue fever/DF), dengue haemorrhagic fever (DHF), hingga syok hipovolemik (dengue shock syndrome/DSS). Hipotesis yang berkaitan dengan tingkat keparahan infeksi DENV meliputi mekanisme antibody-dependent enhancement (ADE) dan keterlibatan sitokin. Hingga kini, belum ada obat antiviral yang efektif untuk mengeradikasi dan mencegah infeksi DENV, sehingga pencegahan berupa vaksin perlu dikembangkan. Kandidat vaksin DNA berbasis gen preM-E serotipe 4 strain Indonesia yang dikembangkan pada penelitian terdahulu disuntikkan ke mencit ddY, kemudian diuji tantang dengan DENV. Pada hari ke-4 dan ke-21 pascauji tantang, keberadaan sitokin IL-2 dalam serum dideteksi dengan metode ELISA. Serum hari ke-21 digunakan dalam uji ADE menggunakan sel K562. Sel limpa diambil pada hari ke-21 pascauji tantang, kemudian keberadaan IL-2 dan antibodi in vitro dideteksi dengan metode ELISA. Tingkat IL-2 tertinggi terdapat pada serum hari ke-4 pada kelompok mencit yang tidak diimunisasi namun diuji tantang, yaitu sebesar 69,83 pg/ml. Konsentrasi IL-2 terendah ditunjukkan oleh kelompok mencit yang diimunisasi namun tidak diuji tantang, yaitu 0 $\mathrm{pg} / \mathrm{ml}$. Pengukuran IL-2 pada serum dan supernatan sel limpa hari ke-21 tidak mendapatkan konsentrasi IL-2. Titer antibodi tertinggi terdapat pada kelompok sel limpa mencit yang diimunisasi, diuji tantang, dan diinduksi in vitro dengan DENV. Hasil uji ADE menunjukkan tingkat pengenceran serum berpengaruh terhadap jumlah sel yang terinfeksi oleh DENV, namun tidak ditemukan kondisi netralisasi dan enhancing. Berdasarkan metode yang digunakan, kandidat vaksin DNA tersebut dapat memicu respon imun seluler dan humoral.
\end{abstract}

Kata kunci: respon imun, vaksin DNA, virus dengue, gen preM-E, IL-2

\section{Abstract}

Dengue virus (DENV) infection can be asymptomatic or cause wide range of clinical symptoms, from mild febrille ilness (dengue fever/DF), dengue haemorrhagic fever (DHF), to hipovolemic shock (dengue shock syndrome/DSS). Hypotheses related to the severity of DENV infection mechanisms including antibody-dependent enhancement (ADE) and cytokines involvement. Until now, there are no effective antiviral drugs can eradicate and prevent DENV infection, therefore the development of vaccines is the alternative. DNA vaccine candidate preM-E serotype 4 strain of Indonesia which was developed in previous studies injected into ddY mice, then challenge with DENV. At day 4 and 21 post-challenge, serum was taken to detect the presence of cytokines IL-2 using ELISA method. Day 21 serum used in the antibody-dependent enhancement (ADE) assay using K562 cell line. Splenocytes were taken at day 21 post-challenge to measure the presence of IL-2 and in vitro antibody using ELISA method. Measurement of IL-2 on day 4 serum produced the highest levels of IL-2 $(69.83 \mathrm{pg} / \mathrm{ml})$ in the group of non-immunized, challenged mice, whereas the lowest concentration $(0 \mathrm{pg} / \mathrm{ml})$ shown by the group of immunized, non-challenged mice. Measurement of IL-2 in serum and splenocytes day 21 did not get the concentration of IL-2. The highest result of in vitro antibody measurements shown by the group of splenocytes from immunized, challenged mice then in vitro induced with DENV. ADE assay results showed that level of serum dilution has effect on the number of dengue-infected cells, but netralization and 
enhancing condition were not found in this assay. Based on this methods, the DNA vaccine candidate can trigger cellular and humoral immune responses.

Keywords: immune response, dengue virus, DNA vaccine, preM-E gene, IL-2

Afiliasi Penulis : 1. Program Studi Magister IImu Biomedik, Fakultas Kedokteran, Universitas Indonesia, Jalan Salemba Raya 6, Jakarta - 10430. 2. Departemen Mikrobiologi, Fakultas Kedokteran, Universitas Indonesia, Jalan Pegangsaan Timur 16, Jakarta - 10320. Korespondensi: eleanor.louana@gmail.com

\section{PENDAHULUAN}

Virus dengue (DENV) termasuk ke dalam genus flavivirus yang menginfeksi manusia melalui perantara nyamuk genus Aedes. Berdasarkan data uji netralisasi, terdapat empat serotipe DENV, yaitu DENV-1, DENV-2, DENV-3, dan DENV-4. ${ }^{1}$ DENV memiliki untai tunggal RNA positif dengan panjang 11 $\mathrm{kb}$, dengan satu open reading frame (ORF) yang mengkode tiga protein struktural yaitu kapsid (C), prekursor membran (preM), dan envelope (E); serta tujuh protein nonstruktural (NS1, NS2a, NS2b, NS3, NS4a, NS4b, dan NS5). Virion dengue berbentuk bola dengan diameter 50 - $60 \mathrm{~nm}$. Bagian luar virion immature (diameter $60 \mathrm{~nm}$ ) terdiri dari protein preM-E (premembran), setelah mengalami pematangan peptida preM akan terlepas sehingga virion hanya memiliki protein $\mathrm{E}$ dan diameter berubah menjadi $50 \mathrm{~mm}^{2}$

Infeksi DENV menyebabkan penyakit serius di area tropis dan subtropis seperti kawasan Asia Tenggara dengan perkiraan 50 juta infeksi terjadi setiap tahun dan lebih dari 2.5 juta orang beresiko terinfeksi. ${ }^{3}$ Infeksi yang disebabkan oleh keempat serotipe DENV terkadang asimtomatis atau dapat juga menunjukkan gejala klinis yang luas, berkisar dari flu ringan/dengue fever (DF), dengue haemorrhagic fever (DHF) yang ditandai dengan demam akut, trombositopenia, netropenia dan pendarahan, hingga ben- tuk paling bahaya yaitu dengue shock syndrome (DSS) ${ }^{4}$

Salah satu hipotesis yang diajukan untuk menjelaskan imunopatogenesis DENV dengan tingkat keparahan penyakit yang tinggi adalah antibody-dependent enhancement (ADE), yang didefinisikan secara in vitro sebagai kondisi konsentrasi antibodi penetralisir spesifik DENV dibawah level netralisasi justru menjadi faktor penguat infeksi virus terhadap sel target. ${ }^{5}$ Ketika terjadi infeksi sekunder dengan serotipe DENV berbeda, antibodi yang dihasilkan pada waktu infeksi primer akan berikatan dengan DENV namun tidak dapat menetralisir virus tersebut. Sebaliknya, kompleks antibodi-virus tersebut akan mengikat reseptor Fc pada monosit yang bersirkulasi dan membantu virus untuk menginfeksi monosit dengan lebih efisien. Hasilnya adalah terjadi peningkatan replikasi virus dan meningkatkan keparahan infeksi. ${ }^{6}$ Selain ADE, faktor lain yang diduga berperan dalam patogenesis DENV diantaranya respon sel $T$ yang bereaksi silang (cross-reactive) sehingga menghasilkan badai sitokin proinflamatori, adanya aktivasi komplemen, serta keterlibatan reaksi induksi autoantibodi, ${ }^{1}$ namun demikian teori patogenesis yang tepat belum diketahui secara pasti.

Hingga kini, belum ada antiviral dan vaksin yang efektif untuk mencegah dan mengobati infeksi DENV. Berdasarkan 
hipotesis ADE, vaksin DENV yang ideal harus mampu memberikan perlindungan terhadap keempat serotipe DENV dan diharapkan dapat menginduksi respon imun dalam jangka waktu tertentu. Konishi, et al telah mengembangkan vaksin DNA tetravalen yang mengekspresikan sekuen sinyal preM-E tiap serotipe $D E N V^{7,8}$ yang mampu memicu respon antibodi penetralisir dalam jumlah seimbang terhadap keempat serotipe DENV.Laboratorium Mikrobiologi FKUI mengembangkan plasmid berbasisgen preM-E monovalen untuk tiapserotipe DENV sebagai kandidat vaksin DNA yang diimunisasikan pada mencit ddY. Tujuan dari penelitian ini adalah mengevaluasi respon imun seluler dan humoral hewan coba mencit yang telah diimunisasi vaksin DNA monovalen berbasis gen preM-E DENV serotipe 4 serta diuji tantang dengan DENV.

\section{METODE}

\section{Bahan penelitian}

Virus dengue: DENV-1 strain RDS 59/9, DENV-2 strain DS 18/9, DENV-3 strain IDS 39/10 dan DENV-4 strain IDS 96/10 (koleksi Departemen Mikrobiologi FKUI).Galur sel mamalia: sel K56, sel Vero 76 dan sel Vero E6 (diperoleh dari Litbangkes Jakarta), sel limpa dari mencit galur ddY (diperoleh dari Biofarma, Bandung).

\section{Penentuan titer DENV dengan plaque assay}

Supernatan DENV diencerkan berseri hingga $10^{-8}$ dalam 100 ul MEM 2\% FBS, dimasukkan ke dalam plat sumur 24 berisi sel Vero E6 monolayer, diinkubasi selama 2 jam pada suhu $37^{\circ} \mathrm{C} \mathrm{CO}_{2}$
$5 \%$, ditambahkan 500 ul metil selulosa $1,5 \%$ ke dalam tiap sumur dan diinkubasi selama 7 hari pada suhu $37^{\circ} \mathrm{C} \mathrm{CO}_{2} 5 \%$. Setelah 7 hari, sel difiksasi dengan 500 ul larutan formalin $10 \%$ dan diwarnai dengan gentian ungu. Plak yang terbentuk pada tiap sumur kemudian dihitung untuk menentukan titer virus.

\section{Penginduksian dan pemanenan sel limpa mencit ddY}

Mencit galur ddY yang telah diimunisasi dan yang tidak diimunisasi dengan plasmid pUM-prM/E-D4 pada hari ke-21 pascauji-tantang, diambil darah retro orbital kemudian dimatikan untuk dilakukan reseksi limpa. Suspensi sel limpa dengan jumlah $10^{7} \mathrm{sel} / \mathrm{ml}$ diinduksi masingmasing dengan DENV-1 strain RDS 59/9, DENV-2 strain DS 18/9, DENV-3 strain IDS 39/10 dan DENV-4 strain IDS 96/10, moi 0,1. Pada kelompok kontrol tidak dilakukan infeksi. Panen sel limpa dilakukan setiap hari selama 7 hari.

\section{ELISA (Enzyme-linked immunosor- bent assay)}

a. Sandwich ELISA untuk mendetek-si antibodi. Plat ELISA di-coating dengan antigen dengue (1: 1000). Sampel diin-kubasi pada plat selama 1 jam, kemu-dian ditambahkan antibodi sekunder anti-mouse IgGHRP (1:1000) inkubasi 1 jam, kemudian direaksikan dengan substrat TMB : $\mathrm{H}_{2} \mathrm{O}_{2}$ (1:1). Absorban dibaca dengan ELISA reader (Biorad) pada panjang gelombang $450 \mathrm{~nm}$.

b. ELISA untuk mengukur konsen-trasi IL-2 ELISA dilakukan menggunakan kit IL-2 Quantikine® (R\&D Systems), absorban dibaca dengan ELISA rea- 
der (Biorad) pada panjang gelombang $450 \mathrm{~nm}$.

\section{Antibody-Dependent Enhancement (ADE) assay}

ADE assay dilakukan berdasarkan metode Konishi dan Miyagawa ${ }^{9}$ menggunakan poly-L-lysine coated 96 well plates karena sifat sel K562 yang semiadherent. Pada tiap sumur plat poly-Llysine (Biocoat, BD Falcon)ditumbuhkan sel K562 sebanyak $10^{5}$ sel dalam 100 ul RPMI 1640-10\% FBS dan diinkubasi selama 24 jam pada suhu $37^{\circ} \mathrm{C} \mathrm{CO}_{2} 5 \%$. Serial pengenceran $10^{-1}-10^{-6}$ serum mencit ddY yang telah disuntikkan plasmid pUM-prM/E-D4 dan telah diuji tantang dengan DENV, beserta kontrol serum mencit yang tidak diberi perlakuan. DENV serotipe 4 IDS 96/10 sebanyak $10^{4} \mathrm{PFU}$ (moi 0,1 PFU/sel) dicampurkan dengan serial pengenceran serum mencit, sebagai kontrol adalah keempat serotipe DENV dalam medium RPMI 1640-bebas serum sebanyak 8 sumur. Campuran DENV-serum dan kontrol diinkubasi pada suhu $37^{\circ} \mathrm{C}$ selama 2 jam. Setelah inkubasi, dimasukkan ke dalam sumur plat berisi sel K562, kemudian diinkubasi pada suhu $37^{\circ} \mathrm{C} \mathrm{CO} 25$ selama 48 jam. Adanya infeksi sel oleh DENV diperiksa dengan uji focus menggunakan imunoperoksidase.

\section{Kaji etik}

Penelitian ini telah memenuhi evaluasi kaji etik yang disetujui FKUI dengan nomor surat 341/PT02.FK/ETIK/2010 dan 145/H2/F1/ETIK/2013.

\section{HASIL DAN PEMBAHASAN}

Pengukuran kadar IL-2 pada serum dan supernatan sel limpa mencit sebagai penanda respon imun selular

\section{a. Pengukuran kadar IL-2 pada standar IL- 2 Quantikine ${ }^{\circledR}$ (R\&D Systems)}

Pengukuran kadar IL-2 dilakukan pada standar IL-2 Quantikine ${ }^{\circledR}$ (R\&D Systems) untuk mendapatkan kurva standar. Kurva standar kadar IL-2 yang dihasilkan memiliki nilai $r^{2}=0,9931$ yang berarti mendekati linear (Gambar 1), dengan rumus kurva standar $y=0,0012 x$ $+0,1812(y=$ OD dan $x=$ konsentrasi IL$2(\mathrm{pg} / \mathrm{ml}))$.

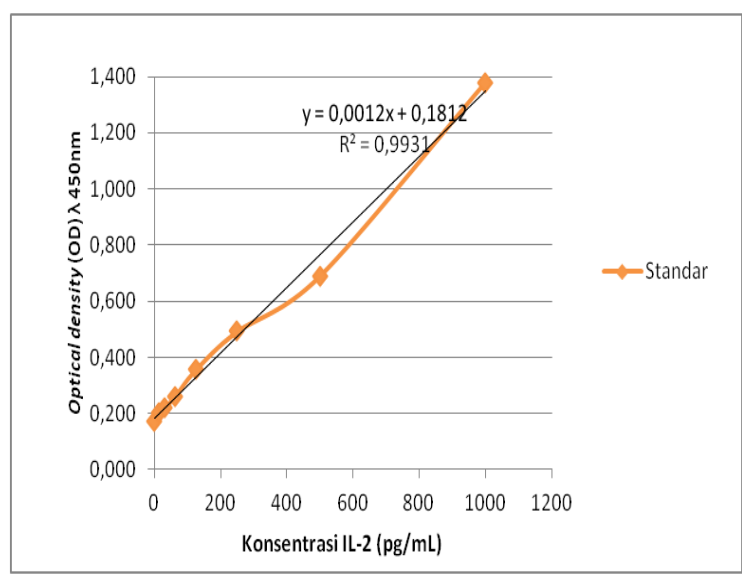

Gambar 1. Kurva standar pengukuran kadar IL-2 mencit menggunakan Quantikine ${ }^{\circledR}$ (R\&D Systems)

b. Pengukuran kadar IL-2 pada serum hari ke-21 pascauji tantang dengan DENV dan supernatan sel limpa

Nilai optical density (OD) serum (Gambar 2) dan supernatan sel limpa mencit (Gambar 4) berada di kisaran 
0,141 - 0,175 sedangkan nilai OD standar konsentrasi IL-2 terendah adalah 0,202 ; sehingga ketika diplot dengan rumus kurva standar tidak menghasilkan nilai yang merepresentasikan konsentrasi IL-2 atau dianggap $0 \mathrm{pg} / \mathrm{ml}$.

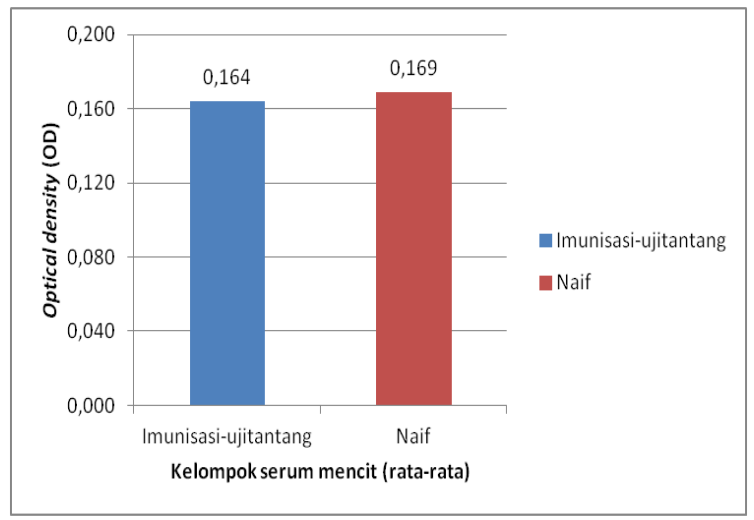

Gambar 2. Grafik OD ( $\lambda 450 \mathrm{~nm}$ ) IL-2 pada serum mencit DENV4 hari ke-21 pascauji tantang dengan DENV. Hasil merupakan rata-rata dari 6 serum/kelompok.

Pada supernatan sel limpa mencit tidak didapatkan kandungan IL-2, baik pada sel limpa yang diimunisasi maupun yang tidak diimunisasi. Hal tersebut diduga disebabkan karena jumlah populasi sel T aktif pada sel limpa sangat sedikit. Namun demikian, flow cytometri tidak dilakukan, sehingga jumlah sel $\mathrm{T}$ dan sel $B$ aktif tidak diketahui. Berdasarkan grafik (Gambar 3), terlihat bahwa OD supernatan kelompok sel limpa mencit yang diimunisasi lebih tinggi disbandingkan kelompok sel limpa mencit yang tidak diimunisasi.

\section{c. Pengukuran kadar IL-2 pada serum hari ke-4 pasca uji tantang}

Sebagai perbandingan, dilakukan pengukuran kadar IL-2 pada serum mencit hari ke-4 pascauji tantang dengan
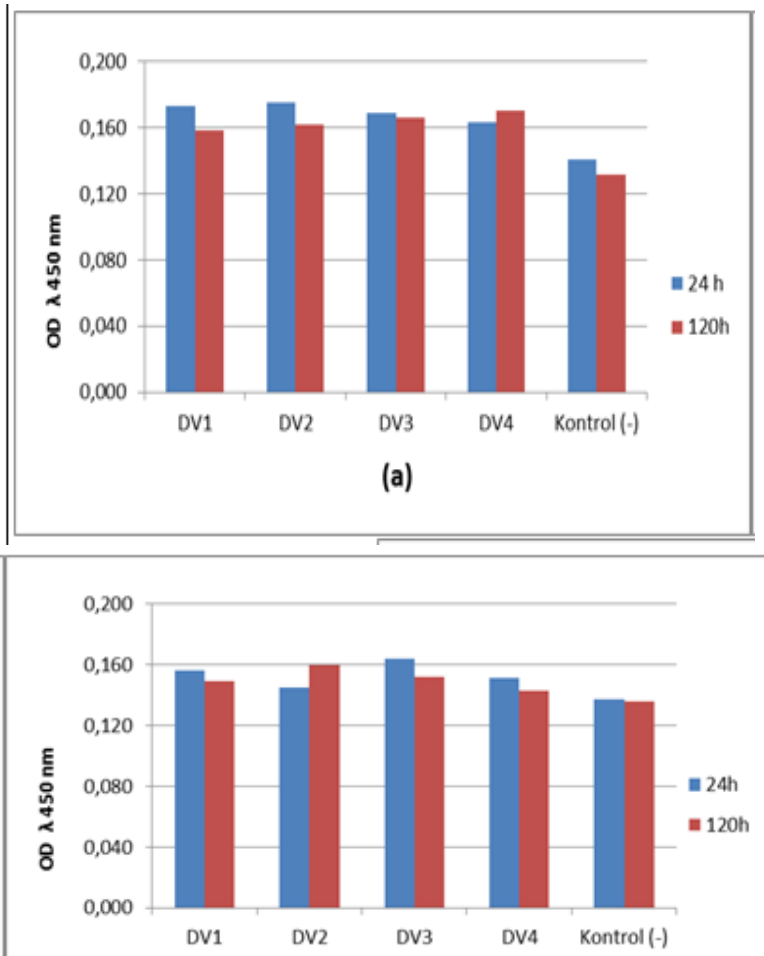

(b)

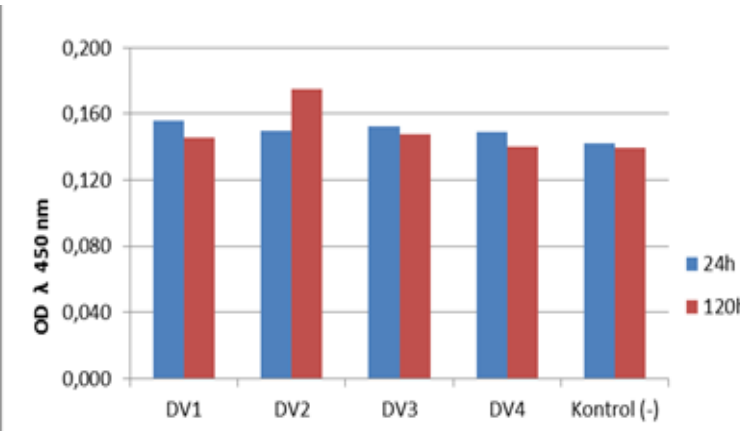

(c)

Gambar 3. Grafik OD ( $\lambda 450 \mathrm{~nm}$ ) IL-2 pada supernatan sel limpa mencit DENV4 hari ke21 pascauji tantang dengan DENV, pada jam ke-24 dan 120 setelah diinduksi dengan DENV 1-4 in vitro. (a.) Kelompok mencit yang diimunisasi plasmid pUM-prM/E-D4, diuji tantang dan diinduksi DENV, (b) kelompok mencit yang diimunisasi, tidak diuji tantang namun diinduksi DENV, dan (c) kelompok mencit naif (tidak diimunisasi, tidak diuji tantang) namun diinduksi DENV.

DENV. Rata-rata Optical Density (OD) yang diperoleh kemudian diplot ke kurva 
standar IL-2. Berdasarkan data yang diperoleh (Gambar 4), kadar IL-2 tertinggi sebesar 69,83 pg/ml ditunjukkan oleh Kelompok 5, yaitu kelompok yang tidak diimunisasi plasmid pUM-prM/E-D4 namun diuji tantang dengan DENV, sedangkan kadar IL-2 tidak terdeteksi pada Kelompok 4 yaitu kelompok mencit yang diimunisasi plasmid pUM-prM/E-D4 dengan dosis $100 \mu \mathrm{g}$ namun tidak diuji tantang.

Kelompok 1 (diimunisasi $25 \mu \mathrm{g}$ plasmid pUM-prM/E-D4 dan diuji tantang) dan Kelompok 3 (diimunisasi 100 $\mu \mathrm{g}$ plasmid pUM-prM/E-D4 dan diuji tantang) yang diharapkan memiliki kadar IL-2 yang tinggi justru hanya menunjukkan nilai sebesar 18,58 pg/ml dan 9,42 $\mathrm{pg} / \mathrm{ml}$. Kelompok 2 yaitu kelompok mencit yang diimunisasi $25 \mu \mathrm{g}$ plasmid pUMprM/E-D4, tidak diuji tantang) menunjukkan kadar IL-2 sebesar 25,67 pg/ml, sedangkan Kelompok 4 yaitu kelompok yang diimunisasi plasmid pUM-prM/E-D4 dengan dosis $100 \mu \mathrm{g}$ namun tidak diuji tantang kadar IL-2 tidak dapat dideteksi (0 pg/ml). Untuk Kelompok 6 (tidak diimunisasi, tidak diuji tantang/naif) menunjukkan kadar IL2 sebesar 25,67 $\mathrm{pg} / \mathrm{ml}$.

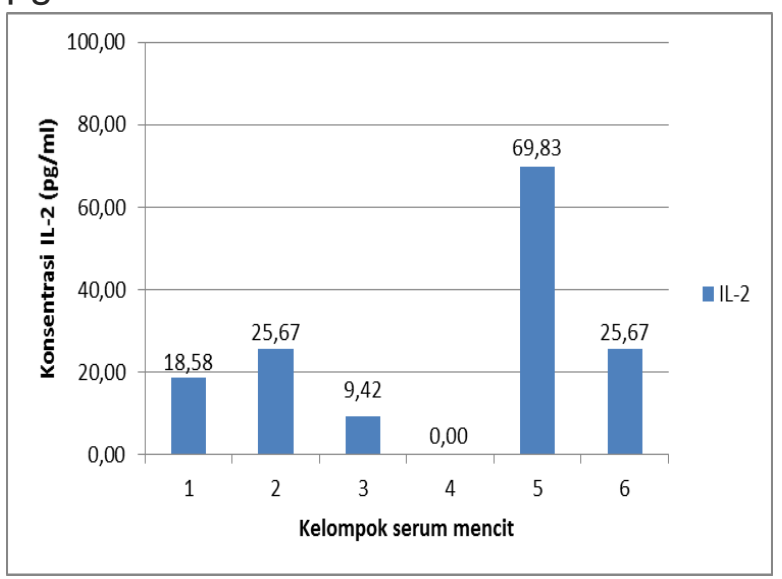

Gambar 4. Grafik konsentrasi IL-2 pada serum mencit DENV4 hari ke-4 pascauji tantang dengan DENV. Keterangan: (1) imuni- sasi $25 \mu \mathrm{g}$, uji tantang (2) imunisasi $25 \mu \mathrm{g}$, tidak uji tantang, (3) imunisasi $100 \mu \mathrm{g}$, uji tantang (4) imunisasi $100 \mu \mathrm{g}$, tidak uji tantang (5) tidak imunisasi, uji tantang (6) naif (tidak diimunisasi, tidak diuji tantang).

\section{Pengukuran antibodi sebagai penanda terdapat sel B memori pada limpa}

Supernatan yang dipilih untuk pendeteksian antibodi adalah supernatan hasil inkubasi jam ke-120 (hari ke-5) dan 144 (hari ke-6) dengan asumsi pada hari tersebut, antibodi yang dihasilkan oleh sel limpa tersedia dalam jumlah yang memadai untuk dideteksi dengan ELISA. Kontrol positif yang digunakan adalah serum pasien yang masing-masing positif terinfeksi keempat serotipe DENV, sedangkan kontrol negatifnya adalah PBS 1X.

Berdasarkan hasil ELISA, kelompok mencit yang diimunisasi plasmid pUM-prM/E-D4, diuji tantang, dan diinduksi dengan keempat serotipe DENV terlihat memiliki nilai OD yang lebih tinggi (Gambar 5A) dibanding kelompok mencit imunisasi, tidak diuji tantang, diinduksi DENV (Gambar 5B) dan kelompok mencit naif, diinduksi DENV (Gambar 5C), baik pada jam ke-120 (hari ke-5) maupun ke-140 (hari ke-6). Setelah diimunisasi, mencit kemudian diuji tantang dengan DENV-4 dan pada hari ke21 setelah uji tantang, limpa diambil untuk dilakukan pengisolasian sel limpa, dengan asumsi terdapat sel B memori yang dihasilkan sewaktu uji tantang dengan DENV, karena sel B memori dihasilkan pada $10-30$ hari pasca terekspos oleh antigen. ${ }^{10} \mathrm{Kemudian}$ sel limpa tersebut diinduksi dengan keempat serotipe DENV (DENV1-4) untuk melihat 
kemungkinan terbentuknya antibodi yang bereaksi silang. Keberadaan antibodi yang bereaksi silang terdapat pada kelompok mencit yang diimunisasi plasmid pUM-prM/E-D4, diuji tantang, dan diinduksi (Gambar 5A), karena menunjukkan nilai OD 0,085-0,095 untuk grup yang diinduksi DEN1-3.
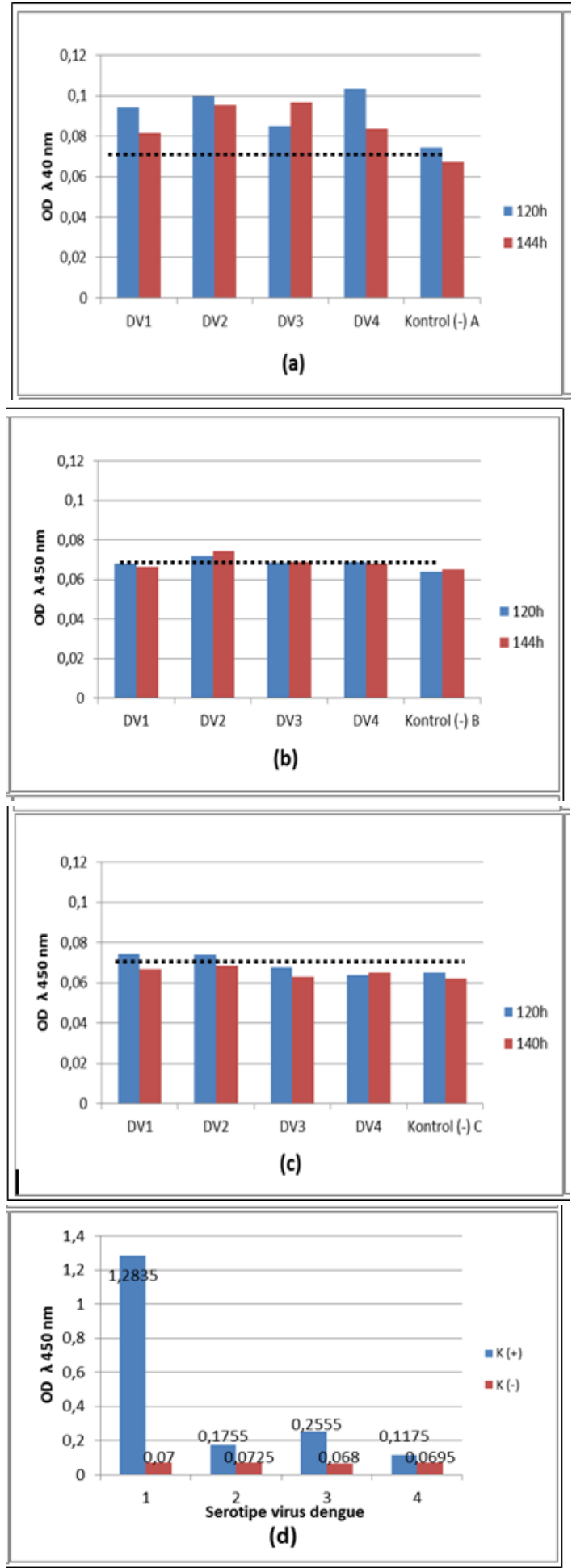

Gambar 5. Grafik optical density (OD) antibodi pada supernatan sel limpa mencit jam ke-120 (hari ke-5) dan 144 (hari ke-6) setelah induksi dengan DENV1-4. (a) Kelompok yang diimunisasi plasmid pUMprM/E-D4, diuji tantang dan diinduksi DENV, (b) Kelompok yang diimunisasi, tidak diuji tantang, dan diinduksi DENV, (c) kelompok naif dan diinduksi DENV, (d) Kontrol positif (+) ELISA : serum pasien positif terinfeksi DENV, kontrol negatif (-) ELISA : PBS. Garis (.....) : batas nilai OD rata-rata kontrol negatif (-) ELISA sebesar 0,07

\section{Pengukuran titer antibodi yang me- nyebabkan kondisi antibody- dependent enhancement (ADE)}

Penelitian ini menggunakan DENV serotipe 4 untuk uji ADE. Setelah dilakukan pewarnaan sel dengan uji fokus imunoperoksidase, didapatkan hasil pada Kelompok 1 yaitu kelompok mencit yang disuntikkan plasmid pUM-prM/E-D4 dosis $25 \mu \mathrm{g}$ dan diujitantang dengan DENV-4, menunjukkan tingkat infeksi sel tertinggi terjadi pada pengenceran serum $1 / 100$, sedangkan pada Kelompok 2 yaitu kelompok mencit yang disuntikkan plasmid pUM-prM/E-D4 dosis $25 \mu \mathrm{g}$ namun tidak diuji tantang, jumlah sel terinfeksi tertinggi berada pada tingkat pengenceran serum 1/10.000 (Gambar $6)$.

Infeksi sel tertinggi di Kelompok 3 yaitu kelompok mencit yang disuntikkan plasmid pUM-prM/E-D4 dosis $100 \mu \mathrm{g}$ dan diujitantang dengan DENV terdapat pada tingkat pengenceran serum 1/1.000.000; sedangkan Kelompok 4 yaitu kelompok mencit yang disuntikkan plasmid pUM-prM/E-D4 dosis $100 \mu \mathrm{g}$ namun tidak diujitantang) berada pada 1/1.000. Pada Kelompok 5 (mencit yang tidak disuntikkan plasmid namun diujitantang dengan DENV), infeksi sel 
terbanyak berada pada tingkat pengenceran 1/10.000; sedangkan pada Kelompok 6 (naif, tidak disuntikkan plasmid dan tidak diujitantang) berada pada tingkat pengenceran 1/10. Cut-off value (rata-rata $\pm 3 S \mathrm{~S}$ ) digunakan untuk menentukan kondisi netralisasi atau enhancing berdasarkan metode Konishi dan Miyagawa. ${ }^{9}$ Berdasarkan grafik tersebut, tidak ditemukan kondisi netralisasi atau pun enhancing pada uji ADE. Sel K562 yang terinfeksi setelah pewarnaan imunohistokimia akan berwarna lebih gelap karena terdapat DENV di dalam sel tersebut (Gambar 7).

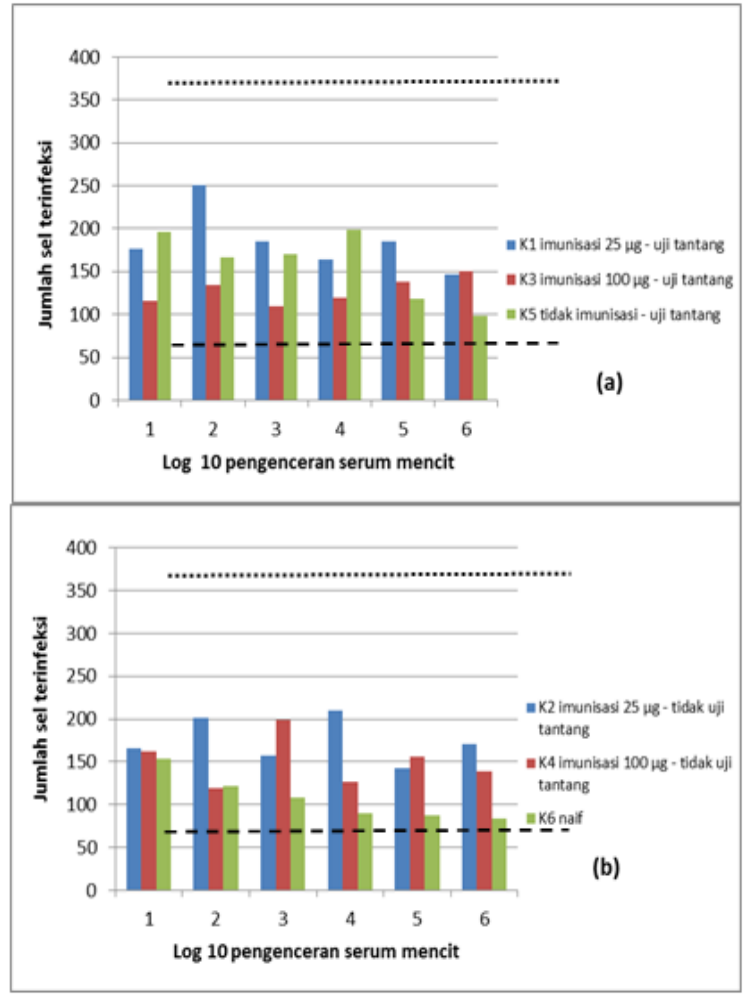

Gambar 6. Grafik jumlah sel K562 terinfeksi pada (A) kelompok imunisasi, diuji tantang; dan (B) kelompok imunisasi, tidak diuji tantang. Cut-off value atas (...): 363,11 ; bawah (---): 61,89 ditentukan berdasarkan rata-rata $\pm 3 S D$

IL-2 dihasilkan sebagian besar oleh sel $\mathrm{T} \mathrm{CD}^{+}$setelah adanya aktivasi sel $\mathrm{T}$ oleh antigen dan kostimulator melalui pengenalan lewat APC. Namun, produksi IL-2 bersifat sementara, dengan sekresi puncak terjadi pada waktu 8-12 jam setelah aktivasi limfosit T. ${ }^{10}$ Pada penelitian ini, pengujian kadar IL-2 dilakukan pada hari ke-21 pascauji tantang dengan DENV, sehingga tidak dapat dideteksi kadarnya pada serum mencit. Untuk melihat aktivasi sel $\mathrm{T}$ dengan memperhatikan kadar IL-2, maka dilakukan uji in vitro menggunakan sel limpa yang diisolasi pada hari ke-21 pascauji tantang dengan DENV.

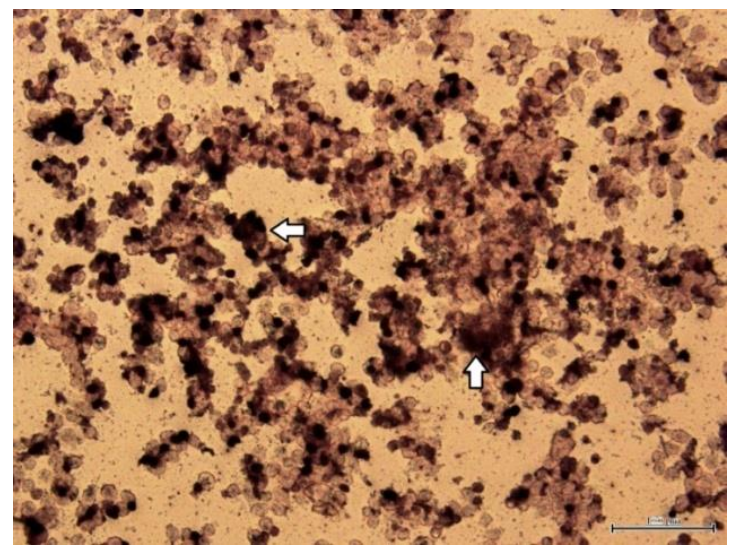

Gambar 7. (tanda panah putih) Sel K562 terinfeksi DENV pengenceran 1/10.000

Pada kelompok serum mencit naif, IL-2 tidak terdeteksi karena mencit tidak mendapat perlakuan pemberian plasmid dan tidak diuji tantang dengan DENV, sehingga tidak ada antigen plasmid yang dipresentasikan oleh APC untuk dikenali oleh sel $\mathrm{T} \mathrm{CD}^{+}{ }^{+}$dan tidak ada aktivasi limfosit yang akan memproduksi IL-2.

Sebagai perbandingan waktu pengambilan serum, dilakukan pengukuran tingkat IL-2 pada serum mencit hari ke-4 pascauji tantang dengan DENV, ratarata optical density (OD) yang diperoleh kemudian diplot ke kurva standar IL-2. 
Berdasarkan data yang diperoleh (Gambar 4), Kelompok 1 yaitu kelompok mencit yang diimunisasi $25 \mu \mathrm{g}$ plasmid pUM-prM/E-D4 dan diuji tantang dan Kelompok 3 yaitu kelompok mencit yang diimunisasi $100 \mu \mathrm{g}$ plasmid pUM-prM/ED4 dan diuji tantang, yang diharapkan memiliki tingkat IL-2 yang tinggi justru hanya menunjukkan konsentrasi sebesar $18,58 \mathrm{pg} / \mathrm{ml}$ dan $9,42 \mathrm{pg} / \mathrm{ml}$. Hal tersebut dapat terjadi karena IL-2 yang disekresikan setelah terjadi aktivasi sel $\mathrm{T}$ yang disebabkan oleh uji tantang dengan DENV, langsung digunakan untuk stimulasi proliferasi dan ekspansi klonal sel T, sehingga konsentrasi IL-2 terlarut yang dapat diukur hanya tersedia dalam jumlah sedikit.

Pada pengukuran IL-2 Kelompok 2 yaitu kelompok mencit yang diimunisasi $25 \mu \mathrm{g}$ plasmid pUM-prM/E-D4, tidak diuji tantang terdapat konsentrasi IL-2 sebesar 25,67 pg/ml, menandakan adanya paparan antigen plasmid yang mengaktifkan sel $\mathrm{T}$ sehingga dapat memproduksi IL-2. Konsentrasi IL-2 terlarut pada Kelompok 2 dideteksi dalam jumlah yang lebih tinggi dibandingkan kedua kelompok yang diimunisasi dan diuji tantang dengan DENV, hal ini diduga dapat disebabkan karena IL-2 yang diproduksi oleh sel $\mathrm{T}$ tidak langsung digunakan untuk proliferasi dan diferensiasi sel $\mathrm{T}$. Karena Kelompok 2 tidak diuji tantang dengan DENV, tidak ada antigen viral yang beredar dalam sistem sirkulasi hewan coba, sehingga tidak dibutuhkan sel T dalam jumlah besar.

Pengukuran kadar IL-2 pada Kelompok 4 yaitu kelompok mencit yang diimunisasi plasmid pUM-prM/E-D4 dengan dosis $100 \mu \mathrm{g}$ namun tidak diuji tantang menunjukkan konsentrasi IL-2 sebesar $0 \mathrm{pg} / \mathrm{ml}$, atau tidak dapat dideteksi. Hal tersebut diduga disebabkan oleh antigen plasmid yang tidak dapat dipresentasikan dengan baik oleh APC sehingga limfosit T tidak teraktivasi. Hal tersebut dapat pula dipengaruhi oleh jarak waktu yang lama antara imunisasi terakhir dengan pengambilan sampel yaitu selama 6 minggu. Sedangkan Kelompok 5 yaitu kelompok mencit yang tidak diimunisasi plasmid pUM-prM/E-D4 namun diuji tantang menunjukkan konsentrasi IL-2 tertinggi sebesar 69,83 $\mathrm{pg} / \mathrm{ml}$. Kelompok tersebut dapat dijadikan model infeksi normal, dimana DENV menginfeksi sel, kemudian antigen viral akan dipresentasikan oleh APC kepada sel $T$ naif yang akan memproduksi IL-2. IL-2 merupakan growth factor autokrin yang berperan dalam aktivasi dan proliferasi sel $\mathrm{T}$, sel $\mathrm{B}$, sel natural killer (NK) dan monosit. ${ }^{11}$ Selain itu, IL-2 berperan dalam stimulasi diferensiasi sel $\mathrm{T}$ menjadi sel efektor dan sel memori. Produksi IL-2 tersebut mencapai puncaknya pada waktu 8-12 jam setelah aktivasi limfosit $T$ 10. Adanya produksi IL-2 dalam jumlah yang signifikan pada mencit Kelompok 5 mengindikasikan bahwa telah terjadi aktivasi limfosit $\mathrm{T}$ dalam kurun waktu empat hari setelah uji tantang dengan DENV. Namun, karena tidak dilakukan flow cytometry, tidak diketahui perbandingan jumlah sel $\mathrm{T}$ naif dan aktif pada semua kelompok perlakuan.

Ketika mencit diimunisasi dengan plasmid pUM-prM/E-D4 secara intramuskular, terjadi sintesis protein prM-E dalam sel target, sehingga dapat disekresikan ekstraseluler. Sekresi protein tersebut kemudian dikenali oleh APC dan dipresentasikan kepada sel $\mathrm{T}$ CD4 ${ }^{+}$untuk mengaktifkan sel B. ${ }^{10}$ Proses tersebut adalah respon primer dimana 
terjadi aktivasi sel B naif untuk pertama kali, sehingga terjadi proliferasi dan diferensiasi sel $B$ menjadi sel plasma yang mensekresikan antibodi dan membentuk sel B memori yang akan merespon antigen terpapar pada infeksi berikut-nya.

Pada Kelompok A (diimunisasi, diuji tantang, diinduksi DENV), OD tertinggi terdapat pada grup supernatan sel limpa yang diinduksi dengan DEN-4, yang mengindikasikan terbentuknya antibodi spesifik terhadap DENV-4 yang diproduksi oleh sel B pada limpa mencit. Selain itu, antibodi yang dihasilkan juga dapat bereaksi silang dengan serotipe DENV lain, terlihat dari OD pada grup supernatan yang diinduksi oleh DENV13. Hasil tersebut memperlihatkan bahwa terdapat sel B memori pada limpa mencit yang dapat segera aktif merespon pemaparan antigen DENV pada proses induksi. Namun pada Kelompok B (diimunisasi, tidak diuji tantang, diinduksi DENV) dan Kelompok C (naif, diinduksi DENV), OD yang ditampilkan cenderung rendah dan berada pada ambang batas OD kontrol negatif. Hal ini dapat disebabkan karena tidak ada sel B aktif yang dapat menghasilkan antibodi terhadap DENV sewaktu proses induksi.

Berdasarkan metode uji ADE Konishi dan Miyagawa ${ }^{9}$, sel K562 yang merupakan sel eritroleukemik manusia dipilih karena memilik reseptor Fc pada permukaannya, sehingga dapat berikatan dengan region $\mathrm{Fc}$ antibodi yang terkandung dalam serum. Sel K562 digunakan untuk melihat kondisi enhancement DENV dalam menginfeksi sel yang diperantarai oleh antibodi, karena sel tersebut menunjukkan karakteristik yang menyerupai monosit ${ }^{12}$, yaitu sel target utama infeksi DENV. Ketika berikatan dengan virus, hal yang diharapkan terjadi adalah netralisasi virus oleh antibodi untuk kemudian berlanjut pada proses opsonisasi, fagositosis dan aktivasi komplemen yang bertujuan untuk mengeliminasi virus, ${ }^{10}$ namun pada kondisi enhancement, antibodi subnetralisasi yang berikatan dengan DENV tersebut akan mengikat reseptor Fc pada monosit yang bersirkulasi. Antibodi tersebut membantu virus untuk menginfeksi monosit dengan lebih efisien.

Pemilihan serum mencit yang diimunisasi dan diuji tantang hanya dengan DENV serotipe 4 didasarkan pada hasil pengukuran antibodi penetralisir pada penelitian sebelumnya yang berada di bawah tingkat netralisasi. ${ }^{8}$ Antibodi pada tingkat subnetralisasi tersebut diduga dapat memicu infeksi virus ke dalam sel karena antibodi tersebut tidak mampu menetralisasi virus yang masuk. Namun, hasil uji ADE pada serum mencit hari ke-21 pascauji tantang tidak menunjukkan kondisi netralisasi ataupun enhancing, karena jumlah sel terinfeksi pada seluruh kelompok serum berada di antara nilai batas bawah dan atas cut-off value. Pada penelitian ini tidak dilakukan pengujian ADE menggunakan serotipe DENV yang lain yaitu DENV1-3.

\section{SIMPULAN}

Kandungan IL-2 dapat dideteksi pada serum mencit hari ke-4 pascauji tantang dengan DENV, namun tidak dapat dideteksi pada serum mencit hari ke-21 pascauji tantang dan supernatan sel limpa; antibodi dapat dideteksi pada supernatan sel limpa, dengan kandungan tertinggi terdapat pada kelompok sel limpa yang diimunisasi, diuji tantang 
dan diinduksi in vitro dengan DENV; dan tingkat pengenceran serum berpengaruh terhadap jumlah sel K562 yang terinfeksi oleh DENV, namun tidak ditemukan kondisi netralisasi atau pun enhancing pada uji ADE.

\section{DAFTAR RUJUKAN}

1. Martina BEE., P. Koraka, A.D.M.E. Osterhaus. Dengue Virus Pathogenesis: an Integrated View. Clin Microbiol. Rev. 2009; (22) 4:564-81.

2. Herrero, L.J., A. Zakhary, M.E. Gahan, M.A. Nelson, B.L. Herring, A.J. Hapel, et al. Dengue virus therapeutic intervention strategies based on viral, vector and host factors involved in disease pathogenesis. $J$ Pharm Thera. 2013; 137(2):266-82.

3. Shuo Zhang, M. Liang, W. Gu, C. Li, F. Miao, X. Wang, et al. Vaccination with dengue virus-like particles induces humoral and cellular immune responses in mice. J Virol. 2011; 8:333.

4. Dharma, R., S.R. Hadinegoro, I. Priatni. Disfungsi Endotel Pada Demam Berdarah Dengue. Makara Kesehatan. 2006; (10)1:17-23.

5. Boonnak, K., K.M.Dambach, G.C.Donofrio, B. Tassaneetrithep, M.A.Marovich. Cell Type Specificity and Host Genetic Polymorphisms Influence Antibody-Dependent Enhancement of Dengue Virus Infection. J Virol. 2011; 85(4):1671-83.
6. Whitehead, S. S., J.E. Blaney, A.P. Durbin, B.R. Murphy. Prospects for a dengue virus vaccine. Nat Rev Microbiol. 2007; 5:51828.

7. Konishi, E., M. Yamaoka, I. Kurane, P.W. Mason.A DNA vaccine expressing dengue type 2 virus premembrane and envelope genes induces neutralizing antibody and memory B cells in mice. Vaccine. 2000; 18: 1133-39.

8. Konishi, E., S. Kosugi, J. Imoto. Dengue tetravalent DNA vaccine inducing neutralizing antibody and anamnestic responses to four serotypes in mice. Vaccine. 2006; 24:2200-7.

9. Konishi, E. and Y. Miyagawa. Balance of infection-enhancing and neutralizing antibodies induced by a dengue tetravalent DNA vaccine in a mouse model. Microbes and Infection. 2011; 1-8.

10. Abbas, A.K., A.H. Lichtman, S. Pillai Cellular and Molecular Immunology 6th Edition. Philadelphia, PA: SaundersElsevier; 2007.

11. Garcia, G., B. Sierra, L. Morier, M. Guzmán, M. Alvarez, A.B. Pérez, M.G. Guzmán. Interleukin (IL-2) Levels in Past Dengue Infection. Dengue Bulletin. 2001; (5):1-4.

12. Lozzio, B.B., Lozzio, C.B., Bamberger, E.G., Feliu, A.S. A multipotential leukemia cell line (K-562) of human origin. Proceedings of the Society for Experimental Biology and Medicine; 1981, 166 (4): 546-50. 